\title{
Implementasi Teori Keputusan \\ Penentuan Penerimaan Beasiswa Bagi Mahasiswa FMIPA Universitas Sulawesi Barat
}

\author{
Hirman Rachman ${ }^{* 1}$, Nizar ${ }^{2}$ \\ ${ }^{1,2}$ Universitas Sulawesi Barat \\ email: ${ }^{1}$ manksman04@gmail.com, ${ }^{* 2}$ nizarmandar@gmail.com
}

\begin{abstract}
Abstrak
Saat ini pengelolah lembaga masih menggunakan cara manual untuk menentukan mahasiswa yang berhak menerima beasiswa sehingga pengelolaan data kurang efektif, membutuhkan waktu yang relatif lama dan sering terjadi subjektifitas dari para pengambil keputusan. Untuk mempermudah para pengelolah tersebut dalam menentukan mahasiswa yang berhak menerima beasiswa, maka perlu adanya suatu sistem rekomendasi yang berfungsi untuk membantu melakukan seleksi bagi para calon penerima beasiswa. Penelitian ini terkait pengaplikasian teori pengambilan keputusan yang dibangun dalam suatu sistem dengan menggunakan kombinasi metode Analitical Hierarcy Process (AHP) dan Technique Order Preference by Similarity To Ideal Solution (TOPSIS). AHP digunakan untuk member bobot penilaian pada kriteria yang dikumpulkan dari hasil kajian pustaka dan hasil wawancara dan TOPSIS digunakan dalam proses perangkingan keputusan yang akan diambil sebagai dasar penentuan keputusan. Penelitian ini yang akan diterapkan pada penentuan penerima beasiswa mahasiswa di lingkungan Fakultas Matematika dan Ilmu Pengetahuan Alam Universitas Sulawesi Barat
\end{abstract}

Kata kunci : Analitical Hierarcy Process (AHP), Technique Order Preference by Similarity To Ideal Solution (TOPSIS), Beasiswa FMIPA Unsulbar

\section{PENDAHULUAN}

Undang-undang Dasar Negara Indonesia telah mengamanatkan tentang upaya mencerdaskan kehidupan bangsa. Hal ini menunjukkan bahwa setiap warga Negara usia sekolah mulai dari tingkat dasar hingga perguruan tinggi harus mengenyam pendidikan. Kenyataannya banyak warga negara usia sekolah tersebut yang tidak dapat mengenyam pendidikan, lebih-lebih pendidikan tinggi karena terkendala oleh biaya pendidikan. Ada kalanya mahasiswa mempunyai prestasi tinggi, tetapi terhambat proses studinya, di lain pihak ada mahasiswa yang putus di tengah perjalanan studinya karena alasan ketiadaan biaya. Pemerintah telah berupaya mengurangi angka putus kuliah bagi mahasiswa dengan memberikan bantuan biaya pendidikan berupa beasiswa. Pembiayaan ini umumnya disalurkan melalui penyelenggara pendidikan disertai wewenang dalam penentuan penerima hak beasiswa tersebut.

Lembaga penyelenggaran penyaluran bantuan beasiswa dalam menenuhi banyaknya permohonan bantuan beasiswa mengadakan seleksi terhadap pemohon karena keterbatasan kuota 
JURNAL SAINTIFIK VOL.3 NO.1, JANUARI 2017

yang tersedia. Lembaga penyelenggara melakukan mekanisme dalam rangka menentukan keputusan yang tepat pemberian bantuan beasiswa, Namun banyaknya permohonan dan ragam jenis beasiswa serta kriteria-kriteria yang disyaratkan terkadang membuat lembaga penyelenggara kewalahan jika dilakukan secara manual. Oleh karena itu diperlukan suatu sistem pendukung keputusan yang bisa dijadikan alat bantu untuk memudahkan proses seleksi penerimaan beasiswa

Fakultas Matematika dan Ilmu Pengetahuan Alam Universitas Sulawesi Barat dengan jumlah mahasiswa yang mengajukan permohonan bantuan yang lebih besar dibandingkan keterersediaan kuota beasiswa mengharuskan mengadakan seleksi penerimaan bantuan beasiswa. Latar belakang mahasiswa yang berbeda-beda terhadap kriteria yang disyaratkan membuat seleksi menjadi rumit dan memerlukan banyak sumber daya. Oleh karena itu penelitian ini diharapkan dapat meminimaliskan sumber daya yang diperlukan

\section{METODE PENELITIAN}

Penelitian ini metode yang dipakai dalam pengambilan keputusan seleksi beasiswa adalah Analitical Hierarchy Process (AHP) dan Technique For Order Preference by Similarity to Ideal Solution (TOPSIS). Kedua metode tersebut dipilih karena metode AHP merupakan suatu bentuk model pendukung keputusan dimana peralatan utamanya adalah sebuah hierarki fungsional dengan input utamanya persepsi manusia, yakni dalam hal ini adalah orang yang ahli dalam masalah beasiswa atau orang yang mengerti permasalahan beasiswa. Sedangkan metode TOPSIS merupakan suatu bentuk metode pendukung keputusan yang didasarkan pada konsep bahwa alternatif yang terbaik tidak hanya memiliki jarak terpendek dari solusi ideal positif tetapi juga memiliki jarak terpanjang dari solusi ideal negatif yang dalam hal ini akan memberikan rekomendasi penerima beasiswa yang sesuai dengan yang diharapkan.

\subsection{Analytical Hierarchy Process (AHP)}

AHP merupakan pendekatan dasar pengambilan keputusan. Dalam proses ini pembuatan keputusan dengan menggunakan pairwise comparison yang digunakan untuk membentuk seluruh prioritas untuk mengetahui rangking dari alternatif.

Langkah-langkah dalam metode AHP meliputi:

1. Menyusun hirarki dari permasalahan yang diteliti, permasalahan diuraikan menjadi unsurunsur yaitu tujuan, kriteria, dan alternatif kemudian disusun menjadi struktur hirarki seperti gambar

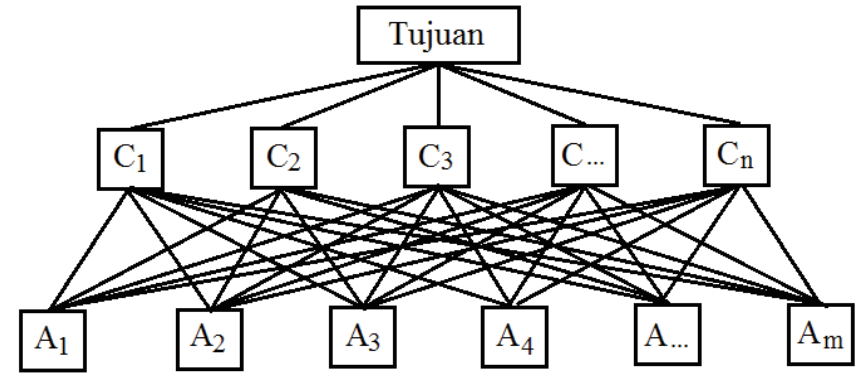

Gambar 1 Bagan Hirarki AHP

2. Penilaian Kriteria dan Alternatif

Kriteria dan alternatif dinilai melalui perbandingan berpasangan.Perbandingan dilakukan berdasarkan kebijakan pembuat keputusan dengan menilai tingkat kepentingan satu elemen terhadapelemen lainnya proses perbandigan berpasangan, dimulai dari proses hirarki paling 
atas yang ditujukan unutk memilih kriteria, misalnya A, kemudian diambil elemnen yang akan dibandingkan, misal $A_{1}, A_{2}, A_{3}, A_{4}, A_{5}$. Maka susunan elemen-elemen yang dibandingkan tersebut.

3. penentuan Prioritas

Untuk setiap kriteria dan alternatif,perlu dilakukan perbandingan berpasangan (pairwise comparison).nilai-nilai perbandingan relatif kemudian diolah untuk menentukan peringkat alternatif dari seluruh alternatif. Pertimbangan-pertimbangan terhadap perbandingan berpasangan untuk memperoleh secara keseluruhan prioritas melalui tahapan-tahapan berikut:

a. Kuadratkan matriks hasil perbandingan berpasangan.

b. Hitung jumlah nilai dari setiap baris, kemudian lakukan normalisaiai matriks.

4. Konsistensi Logis

Perhitungan konsistensi logis dilakukan dengan mengikuti lngkah-langkah sebagai berikut:

a. Mengalikan matriks dengan proritas bersesuaian.

b. Menjumlahkan hasil perkalian per baris.

c. Hasil penjumlahan tipa baris dibagi prioritas bersangkutan dan hasilnyan dijumlahkan.

d. Hasil c dibagi jumlah elemen, akan didapat $\lambda$ maks.

e. Consistenci Indeks $(C I)=\left(\lambda_{\text {maks }}-n\right) /(n-1)$

f. Consistency Ratio $=C R / R I$, dimana $R I$ adalah indeks random consistensi. Jika rasio consisitensi $\geq 0.1$, hasilperhitungan dapat dibenarkan.

g. Menghitung nilai lambda $(\lambda)$ dan consistency indeks $(C I)$ dan vonsistency Ratio $(C R)$ dengan rumus:

$$
\begin{aligned}
& \lambda=\frac{\sum C V}{\sum_{\lambda} n} \\
& C I=\frac{{ }^{2} n}{\eta-1} \\
& C R=\frac{C I}{R I}
\end{aligned}
$$

Dimana:

$\lambda \quad=$ Nilai rata-rata vector consistency

$\mathrm{CV}=$ Consistency Vector

$\mathrm{N} \quad=$ Jumlah faktor yang sedmg dibandingkan

$R I=$ Random Indeks

CR $=$ Consistency Ratio

\subsection{Technique for Orders Preference by Similarity to Ideal Solution (TOPSIS)}

TOPSIS merupakan metode pengambilan keputusan untuk menetapkan alternatif terbaik dari sejumlah alternatif berdasarkan beberapa kriteria tertentu dengan menggunakan konsep bahwa alternatif yang terpilih harus mempunyai jarak terdekat dari solusi positif dan terjauh dari solusi negatif.

Langkah-langkah penyelesaian masalah dengan TOPSIS:

1. Membuat matriks keputusan yang ternormalisasi.

2. Membuat matriks keputusan yang ternormalisasi tebobot. 


\section{JURNAL SAINTIFIK VOL.3 NO.1, JANUARI 2017}

3. Menentukan matriks solusi ideal positif dan solusi ideal negatif.

4. Menentukan jarak antara nilai setiap altenatif dengan matriks solusi ideal positif dan matriks solusi ideal negatif.

5. Menentukan nilai preferensi untuk setiap alternatif.

TOPSIS membutuhkan rating kinerja setiap alternatif $\mathrm{A}_{\mathrm{i}}$ pada setiap kriteria $\mathrm{Cj}$ yang ternormalisasi, yaitu:

$$
r_{i j}=\frac{x_{i j}}{\sqrt{\sum_{i=1}^{m} x_{i j}^{2}}}
$$

$i=1,2, \ldots m$; dan $j=1,2, \ldots n$;

Solusi ideal positif $\mathrm{A}^{+}$dan solusi ideal negatif $\mathrm{A}^{-}$dapat ditentukan berdasarkan rating bobot ternormalisasi $\left(y_{i j}\right)$ sebagai:

$$
y_{i j}=w_{i} r_{i j}
$$

dengan $i=1,2, \ldots m$; dan $j=1,2, \ldots n$;

$$
\begin{aligned}
& A^{+}=\left(y_{1}^{+}, y_{2}^{+}, \ldots, y_{n}^{+}\right), \\
& A^{-}=\left(y_{1}^{-}, y_{2}^{-}, \ldots, y_{n}^{-}\right),
\end{aligned}
$$

dan

$$
\begin{aligned}
& y_{j}^{+}=\left\{\begin{array}{lr}
\max _{i} y_{i j} ; j i k a j \text { adalah atribut keuntungan } \\
\min _{i} y_{i j} ; & \text { jika } j \text { adalah atribut biaya }
\end{array}\right. \\
& y_{j}^{-}= \begin{cases}\max _{\substack{i \\
i j}} ; & \text { jika } j \text { adalah atribut keuntungan } \\
\min _{i} y_{i j} ; & \text { jika } j \text { adalah atribut biaya }\end{cases}
\end{aligned}
$$

Jarak alternatif $\mathrm{A}_{\mathrm{i}}$ dengan solusi ideal positif dirumuskan sebagai:

$$
D_{i}^{+}=\sqrt{\sum_{j=1}^{n}\left(y_{i}^{+}-y_{i j}\right)^{2}}
$$

Jarak antara alternatif $\mathrm{A}_{\mathrm{i}}$ dengan solusi ideal negatif dirumuskan sebagai:

$$
D_{i}^{-}=\sqrt{\sum_{j=1}^{n}\left(y_{i j}-y_{i}^{-}\right)^{2}}
$$

Menentukan nilai preferensi untuk setiap alternatif:

$$
V_{i}=\frac{D_{i}}{D_{i}^{-}-D_{i}^{+}}
$$

Nilai $\mathrm{V}_{\mathrm{i}}$ yang lebih besar menunjukkan bahwa alternatif $\mathrm{A}_{\mathrm{i}}$ lebih dipilih.

\section{HASIL DAN PEMBAHASAN}

Pada bagian ini akan dimulai dengan pembahasan mengenai proses AHP yaitu matriks perbandingan berpasangan yang kemudian dilakukan normalisasi terhadap matriks tersebut dan diperoleh vektor bobot kriteria dari rata-rata baris matriks yang telah ternormalisasi, kemudian 
penentuan Vektor Proritas untuk memperoleh pembobotan hierarki untuk semua kriteria yang disederhanakan

\subsection{Matriks Perbandingan Berpasangan}

Data kriteria yang diambil pada penelitian ini sebanyak empat item, yaitu: nilai semester mahasiswa, nilai extra mahasiswa, penghasilan orang tua mahasiswa, jumlah tanggungan orang tua. Sedangkan data alternatif diambil dari 20 mahasiswa sebagai responden pada penelitian ini. Data kriteria diperoleh dari hasil penilaian yang telah dilakukan oleh pihak universitas dalam hal ini adalah penyelenggaran penyaluran bantuan beasiswa sedangkan nilai perbandingan antar kriteria diperoleh dari hasil wawancara berdasarkan standar skala preferensi AHP pada tabel 2.1.Data penilaian kriteria dan alternatif dapat dilihat pada lampiran 1.Pada penelitian ini langkah pertama yang dilakukan pada AHP adalah menentukan nilai/skor matriks perbandingan berpasangan (pairwise comparison) dengan membandingkan dua kriteria (sepasang) berdasarkan hasil wawancara dengan pihak universitas yaitu penyelenggaran penyaluran bantuan beasiswa. Matriks perbandingan berpasangan antar kriteria yang diperoleh dari hasil penelitian ini adalah sebagai berikut:

Tabel. 1: Matriks perbandingan berpasangan

\begin{tabular}{|l|l|l|l|l|}
\hline kriteria & $\begin{array}{l}\text { Nilai } \\
\text { Semester }\end{array}$ & $\begin{array}{l}\text { Nilai } \\
\text { Ekstra }\end{array}$ & $\begin{array}{l}\text { Penghasilan } \\
\text { Orang Tua }\end{array}$ & $\begin{array}{l}\text { Jumlah Tanggungan } \\
\text { Orang Tua }\end{array}$ \\
\hline Nilai Semester & 1 & 3 & 5 & 6 \\
\hline Nilai Ekstra & $1 / 3$ & 1 & 3 & 2 \\
\hline Penghasilan Orang Tua & $1 / 5$ & $1 / 3$ & 1 & 4 \\
\hline $\begin{array}{l}\text { Jumlah Tanggungan Orang } \\
\text { Tua }\end{array}$ & $1 / 6$ & $1 / 2$ & $1 / 4$ & 1 \\
\hline \begin{tabular}{l} 
Jumlah \\
\hline
\end{tabular} & 1.70 & 4.83 & 9.25 & 13.00 \\
\hline
\end{tabular}

Dari matriks perbandingan berpasangan, kemudian langkah berikutnya yaitu menentukan skor preferensi dengan menjumlahkan nilai pada tiap kolom dibagi dengan jumlah kolom terkait, yang hasilnya merupakan matriks normalisasi (normalized matrix), dan rata-rata tiap barisnya dapat dilihat pada tabel 4.2 :

Tabel. 2: Normalisasi Matriks Perbandingan Berpasangan

\begin{tabular}{|l|l|l|l|l|l|}
\hline kriteria & $\begin{array}{l}\text { Nilai } \\
\text { Semester }\end{array}$ & $\begin{array}{l}\text { Nilai } \\
\text { Ekstra }\end{array}$ & $\begin{array}{l}\text { Penghasilan } \\
\text { Orang Tua }\end{array}$ & $\begin{array}{l}\text { Jumlah } \\
\text { Tanggungan Orang } \\
\text { Tua }\end{array}$ & $\begin{array}{l}\text { Nilai } \\
\text { eigen }\end{array}$ \\
\hline Nilai Semester & 0.588 & 0.621 & 0.541 & 0.462 & 0.553 \\
\hline Nilai Ekstra & 0.196 & 0.207 & 0.324 & 0.154 & 0.220 \\
\hline $\begin{array}{l}\text { Penghasilan } \\
\text { Orang Tua }\end{array}$ & 0.118 & 0.069 & 0.108 & 0.308 & 0.151 \\
\hline $\begin{array}{l}\text { Jumlah } \\
\text { Tanggungan Orang } \\
\text { Tua }\end{array}$ & 0.098 & 0.103 & 0.027 & 0.077 & 0.076 \\
\hline jumlah & 1 & 1 & 1 & 1 & 1 \\
\hline
\end{tabular}




\section{JURNAL SAINTIFIK VOL.3 NO.1, JANUARI 2017}

Selanjutnya, nilai eigen maksimum diperoleh dengan menjumlahkan hasil perkalian jumlah kolom dengan vektor eigen. Nilai eigen maksimum yang dapat diperoleh adalah

$$
\lambda_{\text {maksimum }}=(1.70 \times 0.553)+(4.83 \times 0.220)+(9.25 \times 0.151)+(13 \times 0.076)=4,390
$$

Karena matriks berordo 4 (yakni terdiri dari 4 kriteria), maka nilai indeks konsistensi yang diperoleh adalah

$$
C I=\frac{\lambda_{\max }-n}{n}=\frac{4,390-4}{4}=0.0975
$$

Untuk $\mathrm{n}=4, \mathrm{RI}=0.900$ (tabel Saaty), maka

$$
C R=\frac{C I}{R I}=\frac{0.0975}{0.900}=0.0108
$$

Karena $\mathrm{CR}<0.100$, maka preferensi responden adalah konsisten.

\subsection{Menentukan Vektor Prioritas}

Untuk memperoleh vektor prioritas, setiap unsur pada tabel 4.2 dikalikan dan selanjutnya ditarik akar berpangkat $n$. Hasil dari setiap baris ini kemudian dibagi dengan jumlah dari hasil semua baris.

Tabel. 3 Tabel Pembobotan Hierarki Untuk Semua Kriteria Yang Disederhanakan

\begin{tabular}{|l|l|l|l|l|}
\hline kriteria & $\begin{array}{l}\text { Nilai } \\
\text { Semester }\end{array}$ & $\begin{array}{l}\text { Nilai } \\
\text { Ekstra }\end{array}$ & $\begin{array}{l}\text { Penghasilan } \\
\text { Orang Tua }\end{array}$ & $\begin{array}{l}\text { Jumlah Tanggungan } \\
\text { Orang Tua }\end{array}$ \\
\hline Nilai Semester & 1.00 & 3.00 & 5.00 & 6.00 \\
\hline Nilai Ekstra & 0.33 & 1.00 & 3.00 & 2.00 \\
\hline Penghasilan Orang Tua & 0.20 & 0.33 & 1.00 & 4.00 \\
\hline $\begin{array}{l}\text { Jumlah Tanggungan Orang } \\
\text { Tua }\end{array}$ & 0.17 & 0.50 & 0.25 & 1.00 \\
\hline
\end{tabular}

Dengan demikian, dapat diperoleh vektor prioritasnya, yaitu:

$$
\begin{array}{ll}
\text { Baris I } & : \sqrt[4]{1 \times 3 \times 5 \times 6}=3.080 \\
\text { Baris II } & : \sqrt[4]{0.33 \times 1 \times 3 \times 2}=1.186 \\
\text { Baris III } & : \sqrt[4]{0.20 \times 0.33 \times 1 \times 4}=0.064 \\
\text { Baris IV } & : \sqrt[4]{0.17 \times 0.50 \times 0.25 \times 1}=0.382
\end{array}
$$

Hasil penjumlahan dari nilai akar yang diperoleh adalah

$$
3.080+1.186+0.064+0.382=4,712
$$

Vektor prioritas dihitung dengan cara sebagai berikut.

$$
\frac{3,08}{4,712}=0,654 ; \frac{1,186}{4,712}=0,252 ; \frac{0.064}{4,712}=0,014 ; \frac{0,382}{4,712}=0,081
$$




\subsection{Perhitungan TOPSIS}

Dari perhitungan AHP diperoleh bobot prioritas sebagai berikut.

Tabel. 4 Bobot Prioritas

dimana

\begin{tabular}{|l|l|l|l|}
\hline A & B & C & D \\
\hline 0,654 & 0,252 & 0,014 & 0,081 \\
\hline
\end{tabular}
$\mathrm{A}=$ Nilai Semester;
$\mathrm{B}=$ Nilai Ekstra;
$\mathrm{C}=$ Penghasilan Orang Tua;
$\mathrm{D}=$ Jumlah Tanggungan Orang Tua

Selanjutnya adalah memberikan penilaian tiap kriteria berdasarkan data yang dikumpulkan dari responden sebagai berikut:

\section{Tabel. 5 Tabel Penilaian Kriteria}

\begin{tabular}{|l|l|l|l|l|}
\hline \multirow{2}{*}{$\begin{array}{l}\text { Kode } \\
\text { Mahasiswa }\end{array}$} & \multicolumn{4}{|l|}{ Kriteria } \\
\cline { 2 - 5 } & $\begin{array}{l}\text { Nilai } \\
\text { Semester }\end{array}$ & $\begin{array}{l}\text { Nilai } \\
\text { Ekstra }\end{array}$ & $\begin{array}{l}\text { Penghasilan } \\
\text { Orang Tua }\end{array}$ & $\begin{array}{l}\text { Jumlah } \\
\text { Tanggungan } \\
\text { Orang Tua }\end{array}$ \\
\hline NM 01 & 4 & 5 & 5 & 5 \\
\hline NM 02 & 4 & 4 & 5 & 4 \\
\hline NM 03 & 4 & 5 & 5 & 3 \\
\hline NM 04 & 4 & 5 & 5 & 5 \\
\hline NM 05 & 3 & 4 & 5 & 5 \\
\hline NM 06 & 4 & 4 & 5 & 1 \\
\hline NM 07 & 4 & 4 & 5 & 5 \\
\hline NM 08 & 4 & 4 & 5 & 1 \\
\hline NM 09 & 4 & 5 & 5 & 3 \\
\hline NM 10 & 4 & 4 & 5 & 3 \\
\hline NM 11 & 5 & 4 & 4 & 1 \\
\hline NM 12 & 5 & 4 & 5 & 4 \\
\hline NM 13 & 4 & 4 & 1 & 5 \\
\hline NM 14 & 5 & 5 & 1 & 2 \\
\hline NM 15 & 4 & 4 & 5 & 1 \\
\hline NM 16 & 4 & 4 & 3 & 3 \\
\hline NM 17 & 4 & 5 & 4 & 5 \\
\hline NM 18 & 4 & 4 & 5 & 2 \\
\hline NM 19 & 5 & 4 & 5 & 3 \\
\hline NM 20 & 4 & 5 & 5 & 2 \\
\hline & & & & \\
\hline
\end{tabular}

Hasil perolehan bobot proritas dan penilaian kriteria responden selanjutnya akan dilakukan perangkingan tiap Alternatif alternatif dapat dilakukan dengan pers (1) 


\section{JURNAL SAINTIFIK VOL.3 NO.1, JANUARI 2017}

Maka

$$
\begin{array}{ll}
x_{1}=\sqrt{4^{2}+5^{2}+5^{2}+5^{2}=9,539} & x_{2}=\sqrt{4^{2}+4^{2}+5^{2}+4^{2}}=8,544 \\
r_{11}=\frac{4}{9,539}=0,419 ; & r_{21}=\frac{4}{8,544}=0,468 ; \\
r_{12}=\frac{5}{9,539}=0,524 & r_{22}=\frac{4}{8,544}=0,468 \\
r_{13}=\frac{5}{9,539}=0,524 ; & r_{23}=\frac{5}{8,544}=0,585 \\
r_{14}=\frac{5}{9,539}=0,524 & r_{24}=\frac{4}{8,544}=0,468
\end{array}
$$

Dengan cara yang sama, diperoleh tabel perangkingan alternatif sebagai berikut.

Tabel. 6 Tabel Perangkingan Alternatif

\begin{tabular}{|l|l|l|l|l|}
\hline \multirow{2}{*}{ Nama } & \multicolumn{4}{ll}{ Kriteria } \\
\cline { 2 - 5 } & A & B & C & D \\
\hline NM 01 & 0.419 & 0.524 & 0.524 & 0.524 \\
\hline NM 02 & 0.468 & 0.468 & 0.585 & 0.468 \\
\hline NM 03 & 0.462 & 0.346 & 0.577 & 0.577 \\
\hline NM 04 & 0.419 & 0.524 & 0.524 & 0.524 \\
\hline NM 05 & 0.346 & 0.577 & 0.577 & 0.462 \\
\hline NM 06 & 0.525 & 0.131 & 0.657 & 0.525 \\
\hline NM 07 & 0.442 & 0.552 & 0.552 & 0.442 \\
\hline NM 08 & 0.525 & 0.131 & 0.657 & 0.525 \\
\hline NM 09 & 0.462 & 0.346 & 0.577 & 0.577 \\
\hline NM 10 & 0.492 & 0.369 & 0.615 & 0.492 \\
\hline NM 11 & 0.657 & 0.131 & 0.525 & 0.525 \\
\hline NM 12 & 0.500 & 0.500 & 0.500 & 0.500 \\
\hline NM 13 & 0.525 & 0.657 & 0.131 & 0.525 \\
\hline NM 14 & 0.674 & 0.270 & 0.135 & 0.674 \\
\hline NM 15 & 0.525 & 0.131 & 0.657 & 0.525 \\
\hline NM 16 & 0.566 & 0.424 & 0.424 & 0.566 \\
\hline NM 17 & 0.442 & 0.552 & 0.442 & 0.552 \\
\hline NM 18 & 0.512 & 0.256 & 0.640 & 0.512 \\
\hline NM 19 & 0.577 & 0.346 & 0.577 & 0.462 \\
\hline NM 20 & 0.478 & 0.239 & 0.598 & 0.598 \\
\hline
\end{tabular}

\subsection{Matriks Keputusan Ternormalisasi Terbobot}

Untuk membuat matriks ternormalisasi terbobot menggunakan pers (3), dimana $\mathrm{W}_{\mathrm{j}}$ merupakan bobot prioritas yang diperoleh dari tabel bobot prioritas. 
Untuk $\mathrm{W}_{1}$, maka

$$
\begin{aligned}
& y_{11}=w_{1} r_{11}=0.654 \times 0.419=0.274 \\
& \vdots \quad \vdots \quad \vdots \\
& y_{20,1}=w_{1} r_{20,1}=0.654 \times 0.478=0.313
\end{aligned}
$$

Untuk $\mathrm{W}_{2}$, maka

$$
\begin{aligned}
& y_{12}=w_{2} r_{12}=0.252 \times 0.524=0.132 \\
& \vdots \quad \vdots \quad \text { : } \\
& y_{20,2}=w_{2} r_{20,2}=0.252 \times 0.239=0.060
\end{aligned}
$$

Untuk $\mathrm{W}_{3}$, maka

$$
\begin{aligned}
& y_{13}=w_{3} r_{13}=0.014 \times 0.524=0.007 \\
& \vdots \\
& y_{20,3}=w_{3} r_{20,3}=0.014 \times 0.598=0.008
\end{aligned}
$$

Untuk $\mathrm{W}_{4}$, maka

$$
\begin{aligned}
& y_{14}=w_{4} r_{14}=0.081 \times 0.524=0.042 \\
& \vdots \\
& y_{20,3}=w_{3} r_{20,3}=0.081 \times 0.598=0.048
\end{aligned}
$$

Dengan demikian, diperoleh matriks keputusan ternormalisasi terbobot sebagai berikut.

Tabel. 7 Matriks Keputusan Ternormalisasi Terbobot

\begin{tabular}{|l|l|l|l|l|}
\hline \multirow{2}{*}{ Nama } & \multicolumn{4}{l}{ Kriteria } \\
\cline { 2 - 5 } & A & B & C & D \\
\hline NM 01 & 0.274 & 0.132 & 0.007 & 0.042 \\
\hline NM 02 & 0.306 & 0.118 & 0.008 & 0.038 \\
\hline NM 03 & 0.302 & 0.087 & 0.008 & 0.047 \\
\hline NM 04 & 0.274 & 0.132 & 0.007 & 0.042 \\
\hline NM 05 & 0.227 & 0.145 & 0.008 & 0.037 \\
\hline NM 06 & 0.343 & 0.033 & 0.009 & 0.043 \\
\hline NM 07 & 0.289 & 0.139 & 0.008 & 0.036 \\
\hline NM 08 & 0.343 & 0.033 & 0.009 & 0.043 \\
\hline NM 09 & 0.302 & 0.087 & 0.008 & 0.047 \\
\hline NM 10 & 0.322 & 0.093 & 0.009 & 0.040 \\
\hline NM 11 & 0.429 & 0.033 & 0.007 & 0.043 \\
\hline NM 12 & 0.327 & 0.126 & 0.007 & 0.041 \\
\hline NM 13 & 0.343 & 0.165 & 0.002 & 0.043 \\
\hline NM 14 & 0.441 & 0.068 & 0.002 & 0.055 \\
\hline NM 15 & 0.343 & 0.033 & 0.009 & 0.043 \\
\hline NM 16 & 0.370 & 0.107 & 0.006 & 0.046 \\
\hline NM 17 & 0.289 & 0.139 & 0.006 & 0.045 \\
\hline NM 18 & 0.335 & 0.065 & 0.009 & 0.041 \\
\hline
\end{tabular}




\section{JURNAL SAINTIFIK VOL.3 NO.1, JANUARI 2017}

\begin{tabular}{|l|l|l|l|l|}
\hline NM 19 & 0.378 & 0.087 & 0.008 & 0.037 \\
\hline NM 20 & 0.313 & 0.060 & 0.008 & 0.048 \\
\hline
\end{tabular}

3.5 Menentukan Matriks Solusi Ideal Positif dan Ideal Negatif

Matriks solusi ideal positif dapat ditentukan dengan cara sebagai berikut.

$$
\begin{aligned}
& Y_{1}^{+}=\max (0.274 ; 0.306 ; 0.302 ; \cdots 0.441 ; \cdots ; 0.313)=0.441 \\
& Y_{2}^{+}=\max (0.132 ; 0.118 ; 0.087 ; \cdots 0.165 ; \cdots ; 0.060)=0.165 \\
& Y_{3}^{+}=\max (0.007 ; 0.008 ; 0.008 ; \cdots 0.009 ; \cdots ; 0.008)=0.009 \\
& Y_{4}^{+}=\max (0.042 ; 0.0388 ; 0.047 ; \cdots 0.055 ; \cdots ; 0.048)=0.055
\end{aligned}
$$

Dan matriks solusi ideal negatif dapat ditentukan dengan cara sebagai berikut.

$$
\begin{aligned}
& Y_{1}^{-}=\min (0.274 ; 0.306 ; 0.302 ; \cdots 0.227 ; \cdots ; 0.313)=0.227 \\
& Y_{2}^{-}=\min (0.132 ; 0.118 ; 0.087 ; \cdots 0.033 ; \cdots ; 0.060)=0.033 \\
& Y_{3}^{-}=\min (0.007 ; 0.008 ; 0.008 ; \cdots 0.002 ; \cdots ; 0.008)=0.002 \\
& Y_{4}^{-}=\min (0.042 ; 0.0388 ; 0.047 ; \cdots 0.036 ; \cdots ; 0.048)=0.036
\end{aligned}
$$

3.6 Menentukan Jarak Antara Nilai Terbobot Setiap Alternatif

Menentukan jarak antara nilai terbobot dengan solusi ideal positif dengan formula pers. (4). maka

$$
\begin{aligned}
& D_{1}^{+}=\sqrt{(0.441-0.274)^{2}+(0.165-0.132)^{2}+(0.009-0.007)^{2}+(0.055-0.042)^{2}} \\
& D_{1}^{+}=0.170 \\
& D_{2}^{+}=\sqrt{(0.441-0.306)^{2}+(0.165-0.118)^{2}+(0.009-0.008)^{2}+(0.055-0.038)^{2}} \\
& D_{2}^{+}=0.144 \\
& D_{3}^{+}=\sqrt{(0.441-0.302)^{2}+(0.165-0.087)^{2}+(0.009-0.008)^{2}+(0.055-0.047)^{2}} \\
& D_{3}^{+}=0.160
\end{aligned}
$$

dan seterusnya sehingga diperoleh tabel berikut.

Tabel. 8 Tabel Jarak Antara Nilai Terbobot dengan Solusi Ideal Positif

\begin{tabular}{|l|l|}
\hline$D_{1}^{+}$ & 0.170 \\
\hline$D_{2}^{+}$ & 0.144 \\
\hline$D_{3}^{+}$ & 0.160 \\
\hline$D_{4}^{+}$ & 0.170 \\
\hline$D_{5}^{+}$ & 0.216 \\
\hline$D_{6}^{+}$ & 0.165 \\
\hline$D_{7}^{+}$ & 0.155 \\
\hline$D_{8}^{+}$ & 0.165 \\
\hline
\end{tabular}

\begin{tabular}{|l|l|}
\hline$D_{11}^{+}$ & 0.133 \\
\hline$D_{12}^{+}$ & 0.121 \\
\hline$D_{13}^{+}$ & 0.098 \\
\hline$D_{14}^{+}$ & 0.098 \\
\hline$D_{15}^{+}$ & 0.164 \\
\hline$D_{16}^{+}$ & 0.092 \\
\hline$D_{17}^{+}$ & 0.154 \\
\hline$D_{18}^{+}$ & 0.147 \\
\hline
\end{tabular}




\begin{tabular}{|l|l|}
\hline$D_{9}^{+}$ & 0.160 \\
\hline$D_{10}^{+}$ & 0.140 \\
\hline
\end{tabular}

\begin{tabular}{|l|l|}
\hline$D_{19}^{+}$ & 0.101 \\
\hline$D_{20}^{+}$ & 0.166 \\
\hline
\end{tabular}

Selanjutnya menentukan jarak antara nilai terbobot dengan solusi ideal negatif dengan formula persamaan (5), sehingga

$$
\begin{aligned}
& D_{1}^{-}=\sqrt{(0.274-0.227)^{2}+(0.132-0.033)^{2}+(0.007-0.002)^{2}+(0.042-0.110)^{2}} \\
& D_{1}^{-}=0.110 \\
& D_{2}^{-}=\sqrt{(0.306-0.227)^{2}+(0.118-0.033)^{2}+(0.008-0.002)^{2}+(0.038-0.036)^{2}} \\
& D_{2}^{-}=0.116 \\
& D_{3}^{-}=\sqrt{(0.302-0.227)^{2}+(0.087-0.033)^{2}+(0.008-0.002)^{2}+(0.047-0.036)^{2}} \\
& D_{3}^{-}=0.093
\end{aligned}
$$

dan seterusnya sehingga diperoleh tabel berikut.

Tabel. 9 Tabel Jarak Antara Nilai Terbobot dengan Solusi Ideal Negatif

\begin{tabular}{|l|l|}
\hline$D_{1}^{-}$ & 0.110 \\
\hline$D_{2}^{-}$ & 0.116 \\
\hline$D_{3}^{-}$ & 0.093 \\
\hline$D_{4}^{-}$ & 0.110 \\
\hline$D_{5}^{-}$ & 0.113 \\
\hline$D_{6}^{-}$ & 0.117 \\
\hline$D_{7}^{-}$ & 0.123 \\
\hline$D_{8}^{-}$ & 0.117 \\
\hline$D_{9}^{-}$ & 0.093 \\
\hline$D_{10}^{-}$ & 0.113 \\
\hline
\end{tabular}

\begin{tabular}{|l|l|}
\hline$D_{11}^{-}$ & 0.203 \\
\hline$D_{12}^{-}$ & 0.137 \\
\hline$D_{13}^{-}$ & 0.177 \\
\hline$D_{14}^{-}$ & 0.218 \\
\hline$D_{15}^{-}$ & 0.117 \\
\hline$D_{16}^{-}$ & 0.161 \\
\hline$D_{17}^{-}$ & 0.123 \\
\hline$D_{18}^{-}$ & 0.113 \\
\hline$D_{19}^{-}$ & 0.160 \\
\hline$D_{20}^{-}$ & 0.091 \\
\hline
\end{tabular}

3.7 Mencari Kedekatan Setiap Alternatif Terhadap Solusi Ideal

Mencari kedekatan setiap alternatif terhadap solusi ideal dapat dilakukan dengan menggunakan formula persamaan (6), sehingga diperoleh hasil sebagai berikut.

$$
\begin{array}{ll}
V_{1}=\frac{D_{1}^{-}}{D_{1}^{-}+D_{1}^{+}}=\frac{0.110}{0.110+0.170}=0.392 & V_{11}=\frac{D_{11}^{-}}{D_{11}^{-}+D_{11}^{+}}=\frac{0.203}{0.203+0.133}=0.603 \\
V_{2}=\frac{D_{2}^{-}}{D_{2}^{-}+D_{2}^{+}}=\frac{0.116}{0.116+0.144}=0.447 & V_{12}=\frac{D_{11}^{-}}{D_{11}^{-}+D_{11}^{+}}=\frac{0.137}{0.137+0.121}=0.530 \\
V_{3}=\frac{D_{3}^{-}}{D_{3}^{-}+D_{3}^{+}}=\frac{0.093}{0.093+0.160}=0.369 & V_{13}=\frac{D_{11}^{-}}{D_{11}^{-}+D_{11}^{+}}=\frac{0.177}{0.177+0.098}=0.642
\end{array}
$$




\section{JURNAL SAINTIFIK VOL.3 NO.1, JANUARI 2017}

$$
\begin{array}{ll}
V_{4}=\frac{D_{4}^{-}}{D_{4}^{-}+D_{4}^{+}}=\frac{0.110}{0.110+0.170}=0.392 & V_{14}=\frac{D_{14}^{-}}{D_{14}^{-}+D_{14}^{+}}=\frac{0.218}{0.218+0.098}=0.642 \\
V_{5}=\frac{D_{5}^{-}}{D_{5}^{-}+D_{5}^{+}}=\frac{0.113}{0.113+0.216}=0.343 & V_{15}=\frac{D_{15}^{-}}{D_{15}^{-}+D_{15}^{+}}=\frac{0.117}{0.117+0.164}=0.690 \\
V_{6}=\frac{D_{6}^{-}}{D_{6}^{-}+D_{6}^{+}}=\frac{0.117}{0.117+0.165}=0.415 & V_{16}=\frac{D_{16}^{-}}{D_{16}^{-}+D_{16}^{+}}=\frac{0.161}{0.161+0.092}=0.637 \\
V_{7}=\frac{D_{7}^{-}}{D_{7}^{-}+D_{7}^{+}}=\frac{0.123}{0.123+0.155}=0.442 & V_{17}=\frac{D_{17}^{-}}{D_{17}^{-}+D_{17}^{+}}=\frac{0.123}{0.123+0.154}=0.444 \\
V_{8}=\frac{D_{8}^{-}}{D_{8}^{-}+D_{8}^{+}}=\frac{0.117}{0.117+0.165}=0.415 & V_{18}=\frac{D_{18}^{-}}{D_{18}^{-}+D_{18}^{+}}=\frac{0.113}{0.113+0.147}=0.435 \\
V_{9}=\frac{D_{9}^{-}}{D_{9}^{-}+D_{9}^{+}}=\frac{0.093}{0.093+0.160}=0.369 & V_{19}=\frac{D_{19}^{-}}{D_{19}^{-}+D_{19}^{+}}=\frac{0.160}{0.160+0.101}=0.613 \\
V_{10}=\frac{D_{10}^{-}}{D_{10}^{-}+D_{10}^{+}}=\frac{0.113}{0.113+0.140}=0.446 & V_{20}=\frac{D_{20}^{-}}{D_{20}^{-}+D_{20}^{+}}=\frac{0.091}{0.091+0.166}=0.354
\end{array}
$$

3.8 Perangkingan Berdasarkan Kedekatan Setiap Alternatif Terhadap Solusi Ideal Dari perhitungan sebelumnya, diperoleh nilai akhir sebagai berikut.

Tabel. 10 Tabel Kedekatan Setiap Alternatif Terhadap Solusi Ideal

\begin{tabular}{|l|l|}
\hline Kode Mahasiswa & $V_{i}$ \\
\hline NM 01 & 0.392 \\
\hline NM 02 & 0.447 \\
\hline NM 03 & 0.369 \\
\hline NM 04 & 0.392 \\
\hline NM 05 & 0.343 \\
\hline NM 06 & 0.415 \\
\hline NM 07 & 0.442 \\
\hline NM 08 & 0.415 \\
\hline NM 09 & 0.369 \\
\hline NM 10 & 0.446 \\
\hline
\end{tabular}

\begin{tabular}{|l|l|}
\hline Kode Mahasiswa & $V_{i}$ \\
\hline NM 11 & 0.603 \\
\hline NM 12 & 0.530 \\
\hline NM 13 & 0.642 \\
\hline NM 14 & 0.690 \\
\hline NM 15 & 0.415 \\
\hline NM 16 & 0.637 \\
\hline NM 17 & 0.444 \\
\hline NM 18 & 0.435 \\
\hline NM 19 & 0.613 \\
\hline NM 20 & 0.354 \\
\hline
\end{tabular}

Hasil perangkingan pada tabel di atas dapat dilihat pada tabel berikut.

Tabel. 11 Tabel Perangkingan Tiap Alternatif Berdasarkan Kedekatan Terhadap Solusi Ideal

\begin{tabular}{|l|l|l|c|c|l|l|}
\hline Rangking & $\begin{array}{l}\text { Kode } \\
\text { Mahasiswa }\end{array}$ & $V_{i}$ & Rangking & $\begin{array}{l}\text { Kode } \\
\text { Mahasiswa }\end{array}$ & $V_{i}$ \\
\hline 1 & NM 14 & 0.690 & 11 & NM 18 & 0.435 \\
\hline 2 & NM 13 & 0.642 & 12 & NM 06 & 0.415 \\
\hline
\end{tabular}


JURNAL SAINTIFIK VOL 3 NO.1, JANUARI 2017

\begin{tabular}{|l|l|l|l|l|l|l|}
\hline 3 & NM 16 & 0.637 & 13 & NM 08 & 0.415 \\
\hline 4 & NM 19 & 0.613 & & 14 & NM 15 & 0.415 \\
\hline 5 & NM 11 & 0.603 & & 15 & NM 01 & 0.392 \\
\hline 6 & NM 12 & 0.530 & 16 & NM 04 & 0.392 \\
\hline 7 & NM 02 & 0.447 & 17 & NM 03 & 0.369 \\
\hline 8 & NM 10 & 0.446 & 18 & NM 09 & 0.369 \\
\hline 9 & NM 17 & 0.444 & 19 & NM 20 & 0.354 \\
\hline 10 & NM 07 & 0.442 & 20 & NM 05 & 0.343 \\
\hline
\end{tabular}

Dari tabel di atas, dapat disimpulkan bahwa NM 14 berada pada rangking pertama sehingga paling layak direkomendasikan untuk mendapatkan beasiswa.

\section{KESIMPULAN}

1. Metode ini dapat membantu menyelesaikan permasalahan dalam pengambilan keputusan dengan sumber daya dan kriteria yang majemuk.

2. Metode ini menempatkan NM 14, NM 13, NM 16, NM 19, dan NM 11 sebagai 5 rangking teratas yang direkomendasikan sebagai calon penerima Beasiswa

3. Penetapan perangkingan yang diperoleh relatif bisa diterima setelah diadakan seleksi oleh pihak fakultas yang dilakukan secara mandiri sebagai perbanding

\section{DAFTAR PUSTAKA}

Fitria (2012). Penerapan sistem pendukung keputusan untuk penyaluran dana dan pendataan peningkatan kesejahteraan masyarakat PNPM Mandiri pada Badan Pemberdayaan Masyarakat dan Pemerintahan Desa Kabupaten Mesujidengan metode AHP, Prosiding Seminar Nasional Manajemen Teknologi XV, ITS Surabaya

Juliyanti (2011) Penyelesaian Permasalahan FuzzyMCDM dengan Menggunakan MetodeAHP dan TOPSIS, Tesis, Jurusan Matematika, Institut Teknologi Sepuluh November, Surabaya

Kusumadewi, S.,Hartini, S., Hartati , S., Harjoko, A. dan Wardoyono, R. (2006). Fuzzy Multi Atribut Decision Making (Fuzzy MADM), Grahana Ilmu. Yogyakarta.

Kusumadewi, S., dan Purnomo, H (2010). Aplikasi Logika Fuzzy untuk pendukung keputusan,Edisi 2, Graha Ilmu. Yogyakarta.

Meri Azmi (2014) Pemamfaatan Sistem Pendukung Keputusan Untuk Menentukan Alokasi Dana Kegiatan, Journal Momentum, Vol.16, Hal 74-83

Nuri.G dan Tri. W (2013) Sistem Pendukung Keputusan Pemberian Beasiswa Kepada Peserta Didik Baru Menggunakan Metode TOPSIS, Seminar Nasional Teknologi Informasi dan Komunikasi 2013, Semarang 


\section{JURNAL SAINTIFIK VOL.3 NO.1, JANUARI 2017}

Saaty,T.L. dan Vargas, L.G. (2006). Decision Making With The Analytic Network Process, Springer. United States of America.

Taylor,B.W. (2008).Introduction to Management Science, Edisi 8, Salemba Empat.Jakarta.

Pema.W.B dan Ruben.P (2012) Application of AHP dan TOPSIS Method for Supplier Selection Problem, IOSR Journal of Engineering, www.iosrjen.org 